\title{
A Comparison of the Economic Value for Enteric Methane Emissions with other Biological Traits Associated With Dairy Cows
}

\author{
Matt Bell ${ }^{1 *}$, Jennie Pryce ${ }^{2,3}$, Paul Wilson ${ }^{1}$ \\ The University of Nottingham, School of Biosciences, Sutton Bonington, UK ${ }^{2}$ Department of Economic \\ Development, Jobs, Transport and Resources, AgriBio, 5 Ring Road, Bundoora, Australia ${ }^{3}$ \\ La Trobe University, AgriBio, 5 Ring Road, Bundoora, VIC 3083, Australia \\ matt.bell@nottingham.ac.uk
}

Simple Summary: Since ruminant livestock contribute significantly to global anthropogenic methane emissions they have come under increased scrutiny due to methane being a potent greenhouse gas and pollutant. Before enteric methane can be included in a genetic selection index for breeding, the economic value for enteric methane needs to be derived. An animal model including a partial budget was used to derive economic values for a range of production and fitness (health and fertility) traits typically used in genetic selection of dairy cows with the addition of enteric methane. We found that enteric methane has an economic value of $-£ 1.68$ per $\mathrm{kg}$ methane per lactation and based on the variation seen in the dairy cow population in the UK, genetic selection on enteric methane has potential to increase herd profit per cow and reduce emissions.

Abstract: This is the first study to derive the economic value of enteric methane produced by a ruminant animal. There is considerable interest globally in selecting for low methane-emitting ruminant livestock, as methane is a potent greenhouse gas. However, before enteric methane can be included in a genetic selection index for breeding, the economic value for enteric methane needs to be derived. An animal model including a partial budget was used to derive economic values for a range of production and fitness (health and fertility) traits typically used in genetic selection of dairy cows with the addition of enteric methane. This study found that enteric methane (kilograms/lactation) has an economic value of $-€ 1.68$ per kg increase in methane per lactation. The economic value for enteric methane was of similar magnitude to the traits of milk fat yield ( $£ 1.14$ per unit change in milk fat) and mastitis ( $€ 1.55$ per $\%$ incidence). Based on the variation seen in the dairy cow population in the UK, genetic selection on enteric methane has potential to increase herd profit per cow and reduce emissions. Even if the economic and abatement gains associated with selecting low methane producing livestock are relatively small, reductions in enteric methane emissions appear possible if a reliable and repeatable measure becomes available for use on commercial farms.

Keywords: dairy cattle, biological variation, greenhouse gases, economics

INTRODUCTION

The UK dairy sector produces about 14 million tonnes of milk each year (valued at $£ 4$ billion, from 1.8 million cows), making the UK the tenth largest global milk producing country in the world [1]. The UK has a target to reduce greenhouse gas (GHG) emissions by at least 80\% from 1990 levels by 2050 [2]. Methane is recognized globally as an important GHG and pollutant. Since ruminant livestock contribute significantly to global anthropogenic methane emissions, with $50 \%$ or more of the greenhouse gas emissions produced coming from enteric fermentation [3], they have come under increased scrutiny. Enteric methane is produced in the digestive tract by microorganisms called methanogens as a by-product of anaerobic fermentation (methanogenesis). 
Although a large proportion of the variation in enteric methane emissions from ruminant animals can be explained by diet composition and feed intake $[4,5]$, there is additional variation in enteric methane emissions among animals $[6,7,8]$, which provides the opportunity to select animals based on their methane output. Breeding is a cost effective mitigation strategy [9], as the changes are permanent and cumulative over time. There is considerable research being carried out around the world to develop a method to measure phenotypic and genetic variation in ruminant populations on commercial farms, rather than using a small number of animals in research facilities [10].

Once a reliable method for measuring methane emissions from a large number of animals on commercial farms is developed, selecting animals on methane output will become possible. There are a few recent studies [8, $10,11,12,13,14]$ that have attempted to directly measure individual animal methane emissions from a large number of animals in their normal environment to assess variation among animals and estimate phenotypic and genetic components. In general, these studies have used mobile gas analyzers in different ways, such as a handheld laser gun [13], one-hour measurements with the animal in a box [11] or a trough with a built in gas analyzer [8]. Historically, enteric methane studies have largely been restricted to a small number of animals housed in a respiratory chamber or the tracer gas (SF6) method using a gas canister strapped to the animal, which can impact on the behavior of the animal [15]. The use of respiration chambers or a tracer gas is impractical for large-scale estimation of methane emissions from individual dairy cows on commercial dairy farms. Garnsworthy et al. [16] found that methane emitted by cows during milking was correlated with total daily methane emissions by the same cows when housed subsequently in respiration chambers. The development of mobile gas analyzers placed in robotic milking stations has allowed repeatable measurements of methane emissions from individual animals to be obtained on commercial farms [14,17]. Recent research and development has managed to scale up the number of phenotypes to a level that is of use for genetic evaluations. For example, using a portable air sampler and analyzer unit to measure methane emissions on 3,121 cows from 20 herds, Lassen and Lovendahl [10] estimated that the heritability of methane emissions varied between 0.16 (standard error 0.04 ) and 0.21 (standard error 0.06) for various methane emission traits. The genetic correlation with fat and protein corrected milk was high indicating that selection for production will lead to an improvement (reduction) in methane emissions. However, including methane emissions in the selection objective may further reduce greenhouse gas emissions at a small economic cost. However, before enteric methane can be included as a breeding objective in an economic multi-trait selection index for dairy cows, along with other traits of economic importance, such as production (e.g. milk yield and milk composition), health (e.g. mastitis and lameness) and fertility (e.g. calving interval) traits, its economic value needs to be derived and any potential benefit evaluated. A multi-trait selection index includes the economic value (i.e. income less the cost of inputs that vary with production) of each trait, their heritabilities and genetic and phenotypic correlations between traits in order to calculate optimal index weights for each biological trait of interest [18]. Some traits in (some) breeding objectives may already have beneficial effects on methane emissions, for example, selecting on traits that improve the efficiency of farm systems e.g. residual feed intake and longevity, will also have a favourable effect on overall emissions [19]. More energy efficient animals are known to produce less waste in the form of methane per unit product $[20,21,22]$. Selection on production and fitness traits in the UK using the current index, known as Profitable Lifetime Index (PLI), which currently does not include residual feed intake and methane has already reduced emissions of methane per unit product by about $1.3 \%$ per year over the last 20 years, and will continue to deliver decreases in methane production over the next 15 years, albeit at a slightly slower rate [23]. This reduction in methane emissions per unit product is supported by Bell et al. [24] who found a similar rate of decline of $1.1 \%$ per year for cows selected on increased milk fat and protein production and $1.4 \%$ per year for cows selected to represent the UK average for milk fat and protein production over a similar time period. 


\section{American Research Journal of Agriculture (ARJA)}

The objectives of the current study were thus to 1) derive the economic value for enteric methane and for a range of biological traits used in breeding indices and 2) compare the relative value calculated for enteric methane against these other biological traits.

\section{MATERIALS AND METHODS}

\section{Data}

Expe: The average production values per cow were obtained from approximately 513,000 cows in the UK from the Centre for Dairy Information between the years 2013 to 2015 [25], which is representative of the UK. The data are representative of recorded dairy cows in all regions of the UK. The data includes average number of days for each lactation, milk production at maturity, milk composition and calving intervals (Table 1).

Table 1. Production values included in the model for an average cow

\begin{tabular}{|l|l|l|}
\hline & Units & Average \\
\hline Age at first calving & Days & 730 \\
\hline Lactations & no. & 2.79 \\
\hline Growth rate & kg protein/d & 0.003 \\
\hline Empty body weight & Kg & 550 \\
\hline Mature milk volume ${ }^{1}$ & litres/lactation & 9,806 \\
\hline Milk protein $^{1}$ & $\%$ & 3.4 \\
\hline Milk fat $^{1}$ & $\%$ & 4.1 \\
\hline Gestation $^{2}$ & days & 283 \\
\hline Lactation length $^{1}$ & days & 346 \\
\hline
\end{tabular}

\section{${ }^{1}$ From CDI [25].}

The feed ration for a herd replacement and lactating cow (Table 2) was formulated from pasture, grass silage and dairy concentrate nutrients and least cost diet.

Table 2. Assumed nutrient composition of a herd replacement and lactating cow diet1

\begin{tabular}{|l|l|l|l|}
\hline & Units & Replacement & Lactating \\
\hline CP & g/kg DM & 190 & 196 \\
\hline NDF & g/kg DM & 432 & 392 \\
\hline Ether extract & g/kg DM & 38 & 35 \\
\hline Ash & g/kg DM & 79 & 80 \\
\hline Sugar & g/kg DM & 66 & 80 \\
\hline Metabolizable energy (ME) & MJ/kg DM & 11.6 & 11.4 \\
\hline Digestible energy (DE) ${ }^{2}$ & MJ/kg DM & 13.8 & 13.4 \\
\hline Gross energy (GE) & MJ/kg DM & 19.1 & 19.4 \\
\hline Organic matter digestibility (OMD) ${ }^{2}$ & \% of OM & 78.0 & 77.1 \\
\hline DOMD $^{\text {Digestible CP }}{ }^{2}$ & g/kg DM & 719 & 710 \\
\hline Feeding level $^{1}$ & g/kg DM & 130 & 136 \\
\hline Methane $^{2}$ & & 1.4 & 3.5 \\
\hline
\end{tabular}

Volume 2 
${ }^{1}$ Nutrient compositions from Bell et al. [27] and least cost ration formulated to meet the energy, protein and mineral requirements of the average animal using FeedByte $®$ rationing model version 3.78 (available at http:// www.sruc.ac.uk/info/120110/dairy/354/dairy_services-key_features). Metabolizable and digestible energy were adjusted for feeding level, which was calculated as ME intake as multiples of animal maintenance energy requirements [29].

${ }^{2}$ Digestible energy content estimated from gross energy content and energy lost in faeces; Digestible organic matter in the dry matter (DOMD) was estimated from Rowett Feedingstuffs Evaluation Unit Third Report data [30] as: DOMD $(\mathrm{g} / \mathrm{kg} \mathrm{DM})=472.49 \times \ln (\mathrm{ME})-437.69 ; \%$ OMD $=[\mathrm{DOMD} /(1000-\mathrm{ash})] \times 100$; Digestible CP was estimated by the rearranged equation of Wang et al. [31] as $(\mathrm{kg} / \mathrm{kg} \mathrm{DM})=\mathrm{CP}-[((\ln ((\mathrm{OMD} / 100-0.899) /$ $-0.644) \times 100) /-0.5774) / 1000] \times((1000-a s h)-$ DOMD $)$; Enteric $\mathrm{CH}_{4}$ emissions were estimated as: $\mathrm{CH}_{4}(\mathrm{~g} / \mathrm{kg}$ DM intake) $=0.046 \times$ DOMD $-0.113 \times$ ether extract (all g/kg DM) $-2.47 \times($ feeding level -1$)$.

The least cost ration formulated using FeedByte ${ }^{\circ}$ rationing model that met the energy, protein and mineral requirements of a lactating cow (herd replacement diet in parentheses) consisted of 33 (39)\% pasture, 33 (44)\% grass silage and 34 (17)\% dairy concentrate per kilogram dry matter (DM) intake per lactation. The diet was constrained to a maximum of $50 \%$ pasture per kilogram of fresh feed to reflect grazing in summer period. The cost of feed consumed by each age group was estimated by multiplying total DM intake by ME content and cost per unit ME of the diet (Table 3). The income and costs per cow associated with herd production were average values in the UK over a five year period, with a baseline total output of $£ 1,923$ and total variable costs of $£ 1,397$ (input and output costs shown for steady state herd in Table $\mathrm{C}$ of appendix).

Table 3. Average price for inputs and outputs associated with production for an average herd obtained from Redman [32].

\begin{tabular}{|c|c|c|}
\hline & Units & Average \\
\hline Income & & $£ /$ unit \\
\hline Milk fat ${ }^{1}$ & $\mathrm{~kg}$ & 2.42 \\
\hline Milk protein $^{1}$ & $\mathrm{~kg}$ & 4.40 \\
\hline Bull calf & kg dead weight & 3.60 \\
\hline Heifer calf & head & 150 \\
\hline Culled cow & kg dead weight & 0.82 \\
\hline \multicolumn{3}{|l|}{ Costs } \\
\hline Milking herd replacement ${ }^{2}$ & head & 1080 \\
\hline Enterprise $^{3}$ & kg milk solids & 0.22 \\
\hline Farm labour $^{4}$ & hour & 10 \\
\hline Veterinary labour ${ }^{5}$ & hour & 75 \\
\hline Semen & per straw & 15 \\
\hline Pasture & MJ metabolizable energy & 0.005 \\
\hline Grass silage & MJ metabolizable energy & 0.009 \\
\hline Concentrate & MJ metabolizable energy & 0.020 \\
\hline
\end{tabular}

Volume 2 
${ }^{1}$ Based on milk compositions for milk fat and protein in Table 1 and the average price of 25 pence per liter of milk after price adjustments over a five year period.

${ }^{2}$ Feed costs were deducted to give a non-feed cost associated with a milking herd replacement in the model.

${ }^{3}$ Bedding and dairy supplies.

${ }^{4}$ Assumed labour required of 30 minutes per artificial insemination, 30 minutes per case of severe clinical mastitis and 15 minutes for mild case, 180 minutes for digital lameness, 60 minutes for interdigital lameness, 300 minutes for sole ulcer lameness, 60 minutes for severe, mild and fatal milk fever, twin birth and an assisted birth.

${ }^{5}$ Assumed labour required of 50 minutes per case of severe and fatal clinical mastitis, 15 minutes for digital lameness, 12 minutes for interdigital lameness, 20 minutes per case of sole ulcer lameness, 30 minutes for severe milk fever and 53 minutes for fatal case, 5 minutes for oestrus not observed and 60 minutes for assisted birth.

Model

A detailed and dynamic bio-economic model was constructed in Microsoft Excel by Bell et al. [26, 27] to calculate changes in profit per cow in response to changes in biological traits. More detail on the animal model can be obtained from Bell et al. [26, 27]. Briefly, the economic model dynamically simulates the average cow over a lifetime plus the dairy herd based on input data including production performance and diet composition. A total of 13 age groups were modelled, which included the period between birth and first calving for herd replacements, and 12 lactations. Replacement animals were assumed to calve at 2 years of age. It was assumed that all births resulted in a single live calf, and that $50 \%$ of calves were male and $50 \%$ female. The only animals to leave the system were cull cows, male calves and surplus female calves. All calves sold were assumed to leave the system immediately after birth.

Herd structure was derived using a Markov chain approach. A Markov chain can be used to describe the herd as a vector of states (s) that cows occupy at a given point in time [28], which in this study was each age group. The vector of states at time $t$ is multiplied by a matrix of transition probabilities $(s \times s)$ to give the vector of states at time $t+1$. The probability of a cow progressing to the next lactation (from lactation $n$ to $n+1$ and from lactation 1 to $n$ ) was dependent on the chance of a cow being culled during the current lactation. If the transition matrix is constant for all stages; that is, the model is stationary, then repeated matrix multiplication will produce a fixed long-run vector (steady-state), which is independent of the initial state vector. This long-run steady-state vector provides a useful basis for comparative assessment of alternative herd structures i.e. a change in the number of cows in each age group. For simplicity individual cow values were multiplied by 100 to represent a herd of 100 cows.

It is assumed in the model that energy requirements (of herd replacements and lactating cows) for maintenance, growth, pregnancy, activity and lactation are achieved and that feed intake is always sufficient to achieve energy requirements in the baseline situation. Metabolizable energy (ME) required for maintenance $\left(\mathrm{E}_{\text {maint }}\right)$, gain or loss of body protein $\left(E_{p}\right)$ and lipid $\left(E_{1}\right)$, pregnancy $\left(E_{\text {preg }}\right)$, activity $\left(E_{\text {act }}\right)$ and lactation $\left(E_{\text {lact }}\right)$ for the average cow are presented in Table 4. 
American Research Journal of Agriculture (ARJA)

Table 4. Percentage of total energy (\% of megajoules ME) for a herd replacement and the average lactating dairy cow for maintenance (Emaint), protein growth (Ep), lipid growth (El), pregnancy (Epreg), activity (Eact) and milk production (Elact) over a lifetime

\begin{tabular}{|l|l|l|}
\hline Energy requirement & Replacement & Lactating \\
\hline$E_{\text {maint }}$ & 51.8 & 28.3 \\
\hline$E_{p}$ & 15.6 & 0.2 \\
\hline$E_{1}$ & 22.1 & 0.5 \\
\hline$E_{\text {preg }}$ & 5.3 & 2.8 \\
\hline$E_{\text {act }}$ & 5.2 & 2.8 \\
\hline$\left.E_{\text {lact }}(M)\right)$ & 0.0 & 65.4 \\
\hline Total $(M)$ & 30,434 & 78,007 \\
\hline
\end{tabular}

Feed intake of an animal was calculated from total ME requirement as: Feed intake $(\mathrm{kg} \mathrm{DM} / \mathrm{d})=\mathrm{E}_{\text {total }} \times 1 /(\mathrm{ME}$ $\left.-0.616 \times \mathrm{E}_{\mathrm{CH} 4}-\left(3.8 / \mathrm{GE}_{\mathrm{f}} \times \mathrm{FE}\right)-(29.2 \times \mathrm{DCP} / 6.25)\right)$, where ME, $\mathrm{E}_{\mathrm{CH} 4} \mathrm{GE}_{\mathrm{f}}$ and FE are the metabolizable, enteric methane (both MJ/kg DM), gross faecal and faecal energy (both MJ/kg OM) and DCP is the digestible crude protein $(\mathrm{kg} / \mathrm{kg}$ DM). The values of $0.616,3.8$ and 29.2 are the heat increments associated with fermentation, faeces and urine. A unit reduction in DM intake assumed that ME requirement of the animal remained constant in the baseline and altered situations, but ME intake and associated cost of consumed feed were lower to represent an improvement in residual feed intake.

The loss of nutrients in faeces and urine was calculated from the OM digestibility and digestible crude protein (Table 3). The $\mathrm{N}$ excreted by the animal was partitioned into faeces ( $\mathrm{N}$ intake - digested $\mathrm{N}$ intake) and urine ( $\mathrm{N}$ intake - ( $\mathrm{N}$ retained $+\mathrm{N}$ in faeces)). The loss of dietary energy as enteric methane was calculated using the equation of Bell et al. [33] from nutrients in the diet (Table 3) as:

$$
\begin{aligned}
\mathrm{CH}_{4}(\mathrm{~g} / \mathrm{kg} \mathrm{DM} \text { intake })=0.046 \times \text { DOMD }-0.113 \times \text { ether extract }(\text { both } \mathrm{g} / \mathrm{kg} \mathrm{DM})-2.47 \times \\
\quad(\text { feeding level }-1)
\end{aligned}
$$

where DOMD is estimated from Rowett Feedingstuffs Evaluation Unit Third Report data [30] as:

$$
\operatorname{DOMD}(\mathrm{g} / \mathrm{kg} \mathrm{DM})=472.49 \times \ln (\mathrm{ME})-437.69
$$

The natural logarithm of ME is adjusted for the feed intake level, which is calculated as ME intake as multiples of animal maintenance energy requirements calculated from AFRC [29]. Enteric methane emissions (g/kg DM) were converted to kilograms and megajoules, and kilograms per age group (assuming $55.65 \mathrm{MJ} / \mathrm{kg}$ methane) for further calculations.

The animal's live weight was assumed to be its empty body weight (EBW, $550 \mathrm{~kg}$ ) containing protein, lipid, water, ash and gut fill, which gave an average live weight of $612 \mathrm{~kg}$ for a lactating cow (Table 5) and $233 \mathrm{~kg}$ for a herd replacement (Figure 1). Gut fill was assumed to equate to the water held by dietary fibre content and estimated as 13.2 times the intake of neutral detergent fibre (NDF; kg/d). The body condition score of the cow was estimated from body lipid on a 1 to 5 point scale (Body condition score $=$ body lipid/EBW $\times 0.12+0.36$ ), which gave an average body condition score of 2.7 (Table 5). 


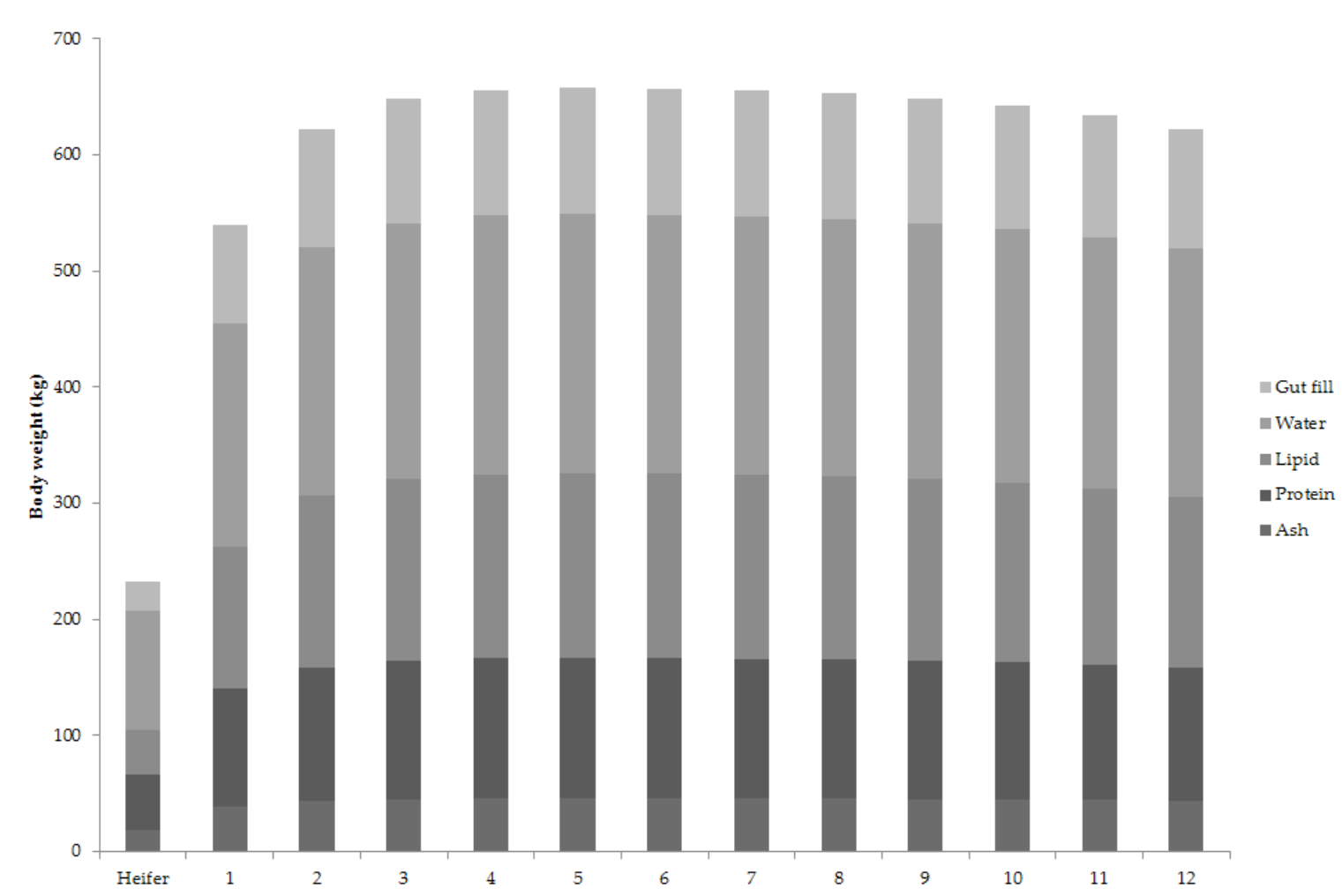

Figure 1. The average mass of protein, lipid, ash, water and gut fill in the live weight of an average heifer replacement and a dairy cow from lactations 1 to 12 with a mature empty body weight of 550 kilograms.

The total amount of milk produced during each lactation was estimated by multiplying the milk production at maturity, from the CDI data, by the proportion of mature productivity for each lactation. The proportion of mature productivity was calculated to be $E_{\text {maint }}-\left(E_{p}+E_{l}\right) /$ maximum of $E_{\text {maint }}-\left(E_{p}+E_{1}\right)$ across lactations. Mature productivity of milk was reached at four lactations for the average cow. Amounts of milk protein, fat and lactose produced were calculated based on milk fat and protein content (Table 1), and an assumed milk content of 5\% lactose. Average yields per lactation were 8,464 litres of milk, $352 \mathrm{~kg}$ of fat and $292 \mathrm{~kg}$ of protein (Table 5).

All cows were assumed to be artificially inseminated. The average number of inseminations per cow was calculated as: No. of inseminations $=1+($ (calving interval (days) - (gestation length (days) + start of oestrus (days))) / 21), where the start of an oestrous cycle was assumed to be 426 days after birth of a herd replacement and 82 days after calving for a lactating cow. Gestation length was assumed to be constant at 283 days (Table 1). This allows for a replacement to enter the herd at 730 days of age and a milking cow to have a 365 day calving interval. The cost of poor fertility was calculated from the cost of each insemination (labour cost per hr / 2 + semen straw cost; Table 4), the additional feed consumed by a milking cow, and the cost of a milking herd replacement per extra day required and assuming no additional milk produced. The main health and fertility problems associated with dairy cows were determined in a previous study by Bell et al. [34], and their associated incidence from that study (Appendix, Table A) and derived cost (Appendix, Table B) were included. The health and fertility problems were: mastitis (clinical and subclinical), lameness (clinical digital/interdigital dermatitis, claw horn lesions), uterine discharge, retained placenta, milk fever, twin births, oestrus not observed and assisted births. The incidence across lactations was calculated by third order polynomial extrapolation 
of the data of Bell et al. [34] except the percentage of cows that had subclinical mastitis was calculated by subtracting the incidence estimated by a cumulative normal distribution with a mean log transformed SCC of 400,000 somatic cells/ml [35] from the 'clinical' incidence obtained from Bell et al. [34]. A cow with mastitis and lameness had an associated cost for treatment and loss of milk. A case of clinical mastitis was assumed to cost $£ 159$ per incidence and subclinical $£ 53$. Other costs were for lameness at $£ 235$, uterine discharge at $£ 86$, retained placenta at $£ 98$, milk fever at $£ 71$, twin birth at $£$ - 47 , oestrus not observed at $£ 16$ and assisted birth at $£ 22$. The costing of health problems are described in more detail in the appendix (Table B) and are similar to those reported by reported by Kossaibati and Esslemont [36] . The average herd production values modelled are shown in Table 5.

Table 5. Modelled traits of average milk volume, milk fat yield, milk protein yield, body condition, dry matter (DM) intake, enteric methane, somatic cell count (SCC), mastitis incidence, lameness incidence, calving interval, survival and long-run steady state per lactation for a 100 cow herd from the Markov chain for an average herd and replacement in the baseline situation

\begin{tabular}{|c|c|c|c|c|c|c|c|c|c|c|c|c|}
\hline & $\begin{array}{l}\text { Milk } \\
\text { vol- } \\
\text { ume }\end{array}$ & $\begin{array}{l}\text { Milk } \\
\text { fat }^{1}\end{array}$ & $\begin{array}{l}\text { Milk } \\
\text { pro- } \\
\text { tein }{ }^{1}\end{array}$ & $\begin{array}{l}\text { Body } \\
\text { condi- } \\
\text { tion }\end{array}$ & $\begin{array}{l}\text { DM } \\
\text { in- } \\
\text { take }\end{array}$ & $\begin{array}{l}\text { Meth- } \\
\text { ane }\end{array}$ & SCC $^{1}$ & $\begin{array}{l}\text { Mas- } \\
\text { titis }\end{array}$ & $\begin{array}{l}\text { Lame- } \\
\text { ness }\end{array}$ & $\begin{array}{l}\text { In- } \\
\text { ter- } \\
\text { val }^{2}\end{array}$ & $\begin{array}{l}\text { Chance } \\
\text { of sur- } \\
\text { vival }^{1}\end{array}$ & $\begin{array}{l}\text { Steady- } \\
\text { state } \\
\text { herd }\end{array}$ \\
\hline Age group & litres & $\mathrm{Kg}$ & $\mathrm{kg}$ & $\begin{array}{l}1 \text { to } 5 \\
\text { scale }\end{array}$ & $\mathrm{kg}$ & $\mathrm{kg}$ & $\begin{array}{l}\text { '000 } \\
\text { cells/ } \\
\mathrm{ml}\end{array}$ & $\%$ & $\%$ & days & $\%$ & $\begin{array}{l}\text { hd/100 } \\
\text { cows }\end{array}$ \\
\hline $\begin{array}{l}\text { Replace- } \\
\text { ment }\end{array}$ & & & & & 3289 & 83 & & & & 730 & & 35.9 \\
\hline 1 & 6609 & 275 & 228 & 2.6 & 6775 & 139 & 129 & 12.9 & 35.8 & 412 & 81.9 & 29.5 \\
\hline 2 & 8623 & 359 & 297 & 2.7 & 8087 & 161 & 154 & 17.0 & 39.3 & 414 & 73.8 & 24.2 \\
\hline 3 & 9354 & 389 & 323 & 2.8 & 8564 & 169 & 203 & 24.9 & 42.4 & 416 & 67.9 & 17.8 \\
\hline 4 & 9629 & 401 & 332 & 2.8 & 8758 & 172 & 258 & 33.0 & 45.3 & 419 & 62.5 & 12.1 \\
\hline 5 & 9729 & 405 & 336 & 2.8 & 8832 & 174 & 310 & 40.0 & 47.8 & 421 & 56.6 & 7.6 \\
\hline 6 & 9786 & 408 & 338 & 2.8 & 8889 & 175 & 359 & 45.7 & 50.1 & 424 & 53.6 & 4.3 \\
\hline 7 & 9806 & 409 & 339 & 2.8 & 8918 & 175 & 392 & 49.2 & 52.1 & 426 & 52.9 & 2.3 \\
\hline 8 & 9760 & 408 & 338 & 2.8 & 8898 & 175 & 413 & 51.3 & 53.8 & 427 & 46.5 & 1.2 \\
\hline 9 & 9647 & 404 & 335 & 2.8 & 8830 & 174 & 422 & 52.1 & 55.2 & 426 & 49.3 & 0.6 \\
\hline 10 & 9439 & 397 & 329 & 2.8 & 8694 & 171 & 433 & 53.1 & 56.4 & 423 & 41.5 & 0.3 \\
\hline 11 & 9157 & 386 & 320 & 2.7 & 8481 & 167 & 441 & 53.9 & 57.3 & 418 & 36.5 & 0.1 \\
\hline 12 & 9023 & 380 & 315 & 2.7 & 8409 & 166 & 405 & 50.5 & 57.9 & 424 & 0 & 0.0 \\
\hline Average $^{3}$ & 8464 & 352 & 292 & 2.7 & 8011 & 164 & 200 & 23.6 & 41.3 & 415 & 70.5 & \\
\hline
\end{tabular}

${ }^{1}$ From CDI [25].

${ }^{2}$ Herd replacements assumed to enter the milking herd at 730 days of age, with calving intervals obtained from CDI [25].

${ }^{3}$ Average for steady state herd and milking cows. 


\section{Economic Values}

The economic value (e.g. income - variable costs = profit or loss) per cow for 12 biological traits was calculated using the bio-economic model and a partial budget by a single unit increase (e.g. $1 \mathrm{~kg}$ milk) in the current state (baseline situation) to create an altered situation. The change in profit in the model due to a single phenotypic standard deviation increase (i.e. change in management) and genetic standard deviation increase (i.e. selective breeding; Table 6) in each of the 12 biological traits studied was also assessed. A single phenotypic and genetic standard deviation change in average herd profit per cow combines the economic value of each trait with its variation within the animal population to provide a comparative assessment of the relative economic importance of each trait.

Table 6. Variation in biological traits and derived economic values in this study from a single increase in each trait

\begin{tabular}{|l|l|l|l|l|}
\hline Trait & Units & $\begin{array}{l}\text { Phenotypic standard } \\
\text { deviation }\end{array}$ & $\begin{array}{l}\text { Genetic standard } \\
\text { deviation }\end{array}$ & Economic value (£) \\
\hline Milk volume & litres & 2147 & 1176 & -0.03 \\
\hline Milk fat yield & $\mathrm{kg}$ & 82 & 42 & 1.14 \\
\hline Milk protein yield & $\mathrm{kg}$ & 63 & 33 & 3.64 \\
\hline Live weight & $\mathrm{kg}$ & 75 & 50 & -0.47 \\
\hline Body condition score & 1 to 5 scale & 0.43 & 0.21 & -46.49 \\
\hline Survival & $\%$ & 29 & 6.5 & 10.19 \\
\hline Residual feed intake & $\mathrm{kg}$ & 603 & 330 & -0.18 \\
\hline Somatic cell count & 000 cells/ml & 57 & 21 & -0.24 \\
\hline Mastitis & $\%$ & 38 & 8 & -1.55 \\
\hline Lameness & $\%$ & 37 & 5 & -2.44 \\
\hline Calving interval & days & 61 & 12 & -2.46 \\
\hline Enteric methane & $\mathrm{kg}$ & 27 & 12 & -1.68 \\
\hline
\end{tabular}

${ }^{1}$ The phenotypic standard deviation ( $\left.\sigma \mathrm{p}\right)$ and heritability $\left(\mathrm{h}^{2}\right)$ were used to calculate the genetic standard deviation ( $\sigma \mathrm{a}$ ) using the formula $\sigma \mathrm{a}=\sigma \mathrm{p} \times \mathrm{h}$, where $\mathrm{h}$ is the square root of the heritability. For most traits the phenotypic standard deviation ( $\sigma \mathrm{p})$ was obtained from CDI [25] and heritability $\left(\mathrm{h}^{2}\right)$ was obtained from Pritchard et al. [37], except for live weight ( $\sigma \mathrm{p}$ from Bell et al. [38] and $\mathrm{h}^{2}$ from Veerkamp and Brotherstone [39]), condition score ( $\sigma \mathrm{p}$ from Banos et al. [40] and $\mathrm{h}^{2}$ from Veerkamp and Brotherstone [39]), residual feed intake ( $\sigma \mathrm{p}$ and $\mathrm{h}^{2}$ from Veerkamp et al. [41]) and enteric methane ( $\sigma \mathrm{p}$ from Yan et al. [22] and $\mathrm{h}^{2}$ from Lassen and Løvendahl [17]). The phenotypic standard deviation ( $\sigma \mathrm{p})$ and heritability $\left(\mathrm{h}^{2}\right)$ for mastitis and lameness were obtained from Pritchard et al. [37].

The biological traits assessed were: milk volume (litres / lactation), milk fat yield (kg / lactation), milk protein yield ( $\mathrm{kg}$ / lactation), live weight (kg), body condition score (1 to 5 point scale), survival (\% / lactation), residual feed intake (kg / lactation), somatic cell count ('000 cells / ml), mastitis incidence (\% / lactation), lameness incidence (\% / lactation), calving interval (days / lactation) and enteric methane (kg / lactation). The traits represent a range of production and fitness traits used to breed dairy cows in the UK, with the addition of feed intake and enteric methane emissions. The economic value for a unit reduction in kilograms of enteric methane per lactation was derived by calculating the extra feed required for energy lost as methane for herd replacements and each lactation, and also including the change in energy lost due to the heat increment from fermentation. 


\section{RESULTS AND DISCUSSION}

\section{Economic Values}

This is the first study to calculate an economic value for enteric methane emissions from any livestock species. The economic value for enteric methane (kg/lactation) was calculated to be $-€ 1.68$ per kg methane (Table 7). The economic value for enteric methane derived in the present study was of similar magnitude to the traits of milk fat yield ( $€ 1.14$ per unit change in milk fat) and mastitis ( $-€ 1.55$ per $\%$ incidence).

Table 7. Economic values derived for a single increase in each trait

\begin{tabular}{|l|l|l|}
\hline Trait & Units & Economic value (E) \\
\hline Milk volume & litres & -0.03 \\
\hline Milk fat yield & $\mathrm{kg}$ & 1.14 \\
\hline Milk protein yield & $\mathrm{kg}$ & 3.64 \\
\hline Live weight & $\mathrm{kg}$ & -0.47 \\
\hline Body condition score & 1 to 5 scale & -46.49 \\
\hline Survival & $\%$ & 10.19 \\
\hline Residual feed intake & $\mathrm{kg}$ & -0.18 \\
\hline Somatic cell count & 000 cells/ml & -0.24 \\
\hline Mastitis & $\%$ & -1.55 \\
\hline Lameness & $\%$ & -2.44 \\
\hline Calving interval & days & -2.46 \\
\hline Enteric methane & $\mathrm{kg}$ & -1.68 \\
\hline
\end{tabular}

Cottle and Connington [42] simulated economic values for methane (in kg/year) from sheep, with values derived from a carbon price ranging from zero to $£ 535$ per tonne of carbon dioxide equivalent $\left(\mathrm{CO}_{2}\right.$-eq.) emissions multiplied by 0.021 . The authors estimated a value of $-€ 0.57$ per $\mathrm{kg}$ methane based on a 'shadow' price of carbon [43] of $£ 27 \mathrm{t} \mathrm{CO}_{2}$-eq. emissions in 2010. The bio-economic model in this study calculated a higher value to that estimated by Cottle and Connington [42]. These authors estimated that for a zero genetic change in methane production, i.e. methane production to be static, a carbon price of $£ 49 \cdot 70 \mathrm{t} \mathrm{CO}_{2}$-eq. emissions would be needed in sheep; this equates to an economic value (kg/year) of about $-€ 0.77$ per $\mathrm{kg}$ methane, which is clearly lower than $-£ 1.68$ in the current study. A value of $-£ 0.77$ or greater was found to have a detrimental impact on performance (Cottle and Connington, [42]), with smaller and less productive animals due to the correlation between production traits and methane production. This also assumes that enteric methane can be measured directly from individual animals to allow inclusion in a genetic selection index. Therefore there is clearly an optimal index weight for enteric methane that would need to be investigated along with other production and fitness traits under genetic selection.

Of the 12 biological traits evaluated in the present study, a 1 unit increase in condition score had by far the largest economic value of $-£ 46.49$ per cow compared to the baseline situation. Other notable economic values were for a $1 \%$ increase in survival ( $€ 10.19$ per cow) and for a $1 \mathrm{~kg}$ increase per lactation in milk protein yield ( $€ 3.64$ per cow). A unit increase from the baseline situation resulted in most traits studied having a negative economic value, except for milk production traits of fat and protein yield, and survival. This study evaluated production and fitness traits that are largely also breeding objectives currently used in UK genetic evaluations, but with some differences in definition of traits such as survival and fertility, and with the addition of live weight, body condition score, feed efficiency and enteric methane. Generally, the economic values calculated in this 
study (Table 6) were similar for the health and fertility traits (allowing for the difference in how lifespan and survival traits are derived) to those currently implemented in UK genetic evaluations[43], with the exception of milk production values which were higher in this study. The higher than previously reported [44] economic values for milk production traits was due to an increase in the average price of milk from 17 pence per liter in previous calculations [45] to 25 pence per liter and the use of the most recent published phenotypic and genetic parameters for the UK [37]. Although assumptions are used to model a cow over its lifetime to derive economic values (along with actual national records), Pryce et al. [18] showed that economic values derived using the current modelling approach are generally robust to these assumptions. Ultimately, the best assumptions available have to be used to complement actual records in order to calculate economic values.

\section{A Phenotypic and Genetic Standard Deviation Change}

Generally, increasing the genetic potential of livestock to produce more (i.e. milk output) increases methane emissions per animal, due to an increase in feed intake $[23,38]$. Comparing the change in profit due to a single phenotypic or genetic standard deviation change in each trait showed that survival is the most important trait in terms of improving profit, with an average increase in profit of $£ 295$ ( $£ 66$ genetic) per cow compared to the baseline situation (Figure 2). This potential change in herd profit would come largely through a change in management rather than genetic progress. Increasing milk protein yield and milk fat yield and decreasing calving interval, feed intake and lameness would also bring notable improvements in profit of $£ 229$ ( $€ 119$ genetic), $£ 93$ ( $£ 47$ genetic), $-£ 149$ (- $£ 30$ genetic), $-£ 107$ (- $£ 59$ genetic) and $-£ 90(-£ 13$ genetic) per cow respectively compared to the baseline. A large part of the variation in methane emissions from dairy cows appears to be genetic (Table 6, Figure 2), which is also the case for the production traits of milk volume, milk fat and protein yield, live weight, body condition and feed intake. Overall, methane has a reasonable economic importance compared to other traits, with an average reduction in profit of $-£ 45$ (- $£ 21$ genetic) per cow compared to the baseline situation (Figure 2). The relative economic importance of methane is between that of live weight and mastitis.

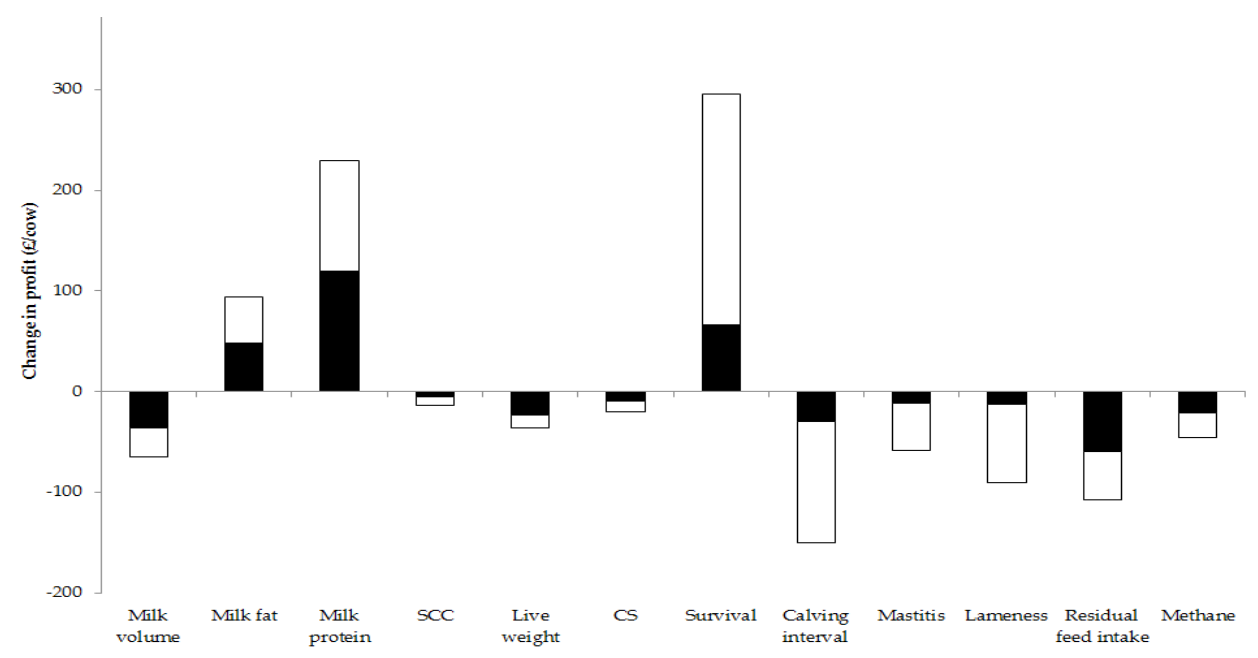

Figure 2. Change in the average herd profit ( $E$ ) per cow for a single phenotypic (both and an) and single genetic (?) standard deviation (SD) increase in milk volume, milk fat yield, milk protein yield, somatic cell count (SCC), live weight, condition score (CS), survival, calving interval, mastitis incidence, lameness incidence, residual feed intake and enteric methane. 
From a range of production and fitness traits, breeding studies $[23,38]$ have found that feed efficiency has a large impact on reducing GHG emissions (methane and nitrous oxide) from dairy systems. The genetic correlation between intake and milk yield has been found to account for just less than half the genetic improvement seen in milk production historically due to an increase in dry matter intake [46]. This implies an apparent improvement indirectly in feed conversion efficiency (milk produced per unit feed intake). The remainder could be due to an increased reliance on body tissue reserves. Therefore, selecting animals for efficient feed utilization (in the form of feed intake and energy lost as methane) should bring both higher production and reduced resource requirements. Residual feed intake (difference between actual and expected feed intake) represents variation in the efficiency of metabolic processes, which is independent of the animal's body size and production level. Furthermore, a study by Bell et al. [33] showed variation in $\mathrm{CH}_{4}$ yield between individual sheep fed the same amount of a given diet in the same environment, which supports the findings $[6,7,8]$ that genetic selection of low emitting animals is possible. Low correlations between residual feed intake and other production traits imply that little or no genetic improvement has previously been made in residual intake as a result of selection on production traits [23]. With a positive genetic correlation between feed utilization efficiency and methane emissions, with an estimated range from 0.18 to 0.84 [6], it can be inferred that selecting cows that are more efficient users of their food will reduce methane production, possibly in the order of $1.1 \%$ to $2.6 \%$ per year. Some studies have suggested that the direct selection of animals on their methane production is of little importance $[47,48]$ given this relationship with feed intake, which is potentially more easily measured and recorded trait. When selection on enteric methane does become available an adjustment and measure or prediction of feed intake will be required. Indeed, it has been shown [6] that feed intake, or even a prediction of intake [49], could be used as a proxy for selecting animals on $\mathrm{CH}_{4}$ emissions, since it explains a large proportion of the variation in emissions.

For a trait such as enteric methane to be included in a multi-trait genetic selection index that includes production and fitness traits similar to those in Table 6 would require phenotypic and genetic components for enteric methane and its correlation with other traits in the breeding objective, which are not currently available. However, if we assume that there is a neutral correlation between a simulated predicted transmitting ability (PTA) for methane and the PLI (with genetic standard deviations of 12 and 80 respectively), then this new PTA for methane multiplied by its economic value of $€-1.68$ can be added to the PLI, and the response to selection is derived as a function of the ratio of the standard deviations multiplied by $\mathrm{r}$ (methane, PLI). Based on these assumptions, by adding methane to the PLI as an additional trait will potentially create a negative correlation of -0.25 between PLI and methane, i.e. methane would reduce through selection on PLI. For every 10 PLI units increase would reduce emissions by $0.4 \mathrm{~kg}$ per cow per lactation and $0.2 \%$ of the average per cow (164 kg, Table 5). If half the 1.8 million dairy cows in the UK are under selection, then this is a saving of 344 tonnes methane per year, which is a permanent and cumulative reduction. Using the same approach to assess feed intake (economic value of $€-0.18$ ) as an additional trait in the PLI would yield a negative correlation of -0.63 with the PLI and lead to a reduction in feed use of $25 \mathrm{~kg} \mathrm{DM} /$ cow/lactation and $0.3 \%$ of the average per cow (Table 5). Having methane in the breeding objective in its own right is likely to lead to greater reductions in methane than relying on improvements in other production or fitness traits.

\section{CONCLUSIONS}

This study found that enteric methane has an economic value of $€-1.68$ per kg per lactation. When combined with the variation in the dairy cow population, the trait of enteric methane has less economic importance for herd profitability compared to survival, milk production traits (composition and volume), calving interval and feed intake for increasing the profitability of dairy herds. Even if the economic gains associated with reductions in enteric methane emissions are small, it is unlikely that other breeding goals are able to account for all the genetic 
variation in methane emissions and therefore there will be some permanent and cumulative improvement with time through selecting low methane emitting animals. However, improvements in correlated traits such as feed efficiency may be more cost-effective in reducing emissions given the difficulty of measuring such phenotypes compared to existing milk recorded production, health and fertility traits.

\section{ACKNOWLEDGMENTS}

We wish to thank Henry Richardson at The Centre for Dairy Information for providing UK herd performance data for this study.

\section{REFERENCES}

1. Agriculture and Horticulture Development Board (AHDB). World milk production. Available online: http:// dairy.ahdb.org.uk/market-information/supply-production/milk-production/world-milk-production/\#. VkEfeLfhDIU (accessed on 9 November 2015)

2. Department of Energy and Climate Change (DECC). Climate Change Act 2008 (UK, London, DECC, 2009). Available online: http://www.legislation.gov.uk/ukpga/2008/27/contents (accessed on 25 November 2015).

3. Steinfeld, H.; Gerber, P.; Wassenaar, T.; Castel, V.; Rosales, M.; de Haan, C. Livestock's long shadow - Environmental issues and options. FAO, Rome, Italy, 2006.

4. Beauchemin, K.A.; Kreuzer, M.; O'Mara, F.; McAllister, T. A. Nutritional management for enteric methane abatement: a review. Aust. J. Exp. Agric. 2008, 48, 21-27.

5. Bell, M.J.; Eckard, R.J. Reducing enteric methane losses from ruminant livestock - its measurement, prediction and the influence of diet. In Livestock Production; Javed, K., Ed; InTech Publishing, Rijeka, Croatia, 2012; pp.135-150.

6. de Haas, Y.; Windig, J.J.; Calus, M.P.L.; Dijkstra, J.; de Haan, M.; Bannink, A.; Veerkamp, R.F. Genetic parameters for predicted methane production and the potential for reducing enteric emissions through genomic selection. J. Dairy Sci. 2011, 94, 6122-6134.

7. Garnsworthy, P.C.; Craigon, J.; Hernandez-Medrano, J.H.; Saunders, N. Variation among individual dairy cows in methane measurements made on farm during milking. J. Dairy Sci. 2012a, 95, 3181-3189.

8. Huhtanen, P.; Krizsan, S.J.; Hetta, M.; Gidlund, H.; Cabezas Garcia, E.H. Repeatability and between cow variability of enteric methane and total carbon dioxide emissions. Advances in Animal Biosciences 2013, 4 , 588.

9. Moran, D.; Barnes, A.; McVittie, A. The rationale for Defra investment in R\&D underpinning the genetic improvement of crops and animals (IF0101). Final report to Defra. London, UK, 2007.

10. Lassen, J.; Løvendahl, P. Heritability estimates for enteric methane emission from Holstein cattle measured using noninvasive methods. J. Dairy Sci. 2016, 99, 1959-1967.

11. Robinson, D.L.; Goopy, J.P.; Hegarty, R.S.; Vercoe, P.E. Repeatability, animal and sire variation in 1-hr methane emissions and relationship with rumen volatile fatty acid concentrations. In Proceedings of 9th World Congress in Genetics Applied to Livestock. Leipzig, Germany, 2010; p. 712.

12. Lassen, J.; Løvendahl, P.; Madsen, J. Accuracy of noninvasive breath methane measurements using Fourier transform infrared methods on individual cows. J. Dairy Sci. 2012, 95, 890-898.

13. Pickering, N.K.; Chagunda, M.G.G.; Banos, G.; Mrode, R.; McEwan, J.C.; Wall, E. Genetic parameters for predicted methane production and laser methane detector measurements. J. Anim. Sci. 2015, 93, 11-20. 
14. Bell, M.J.; Potterton, S.; Craigon, J.; Saunders, N.; Wilcox, R.; Hunter, M.; Goodman, J.R; Garnsworthy, P.C. Variation in enteric methane emissions among cows on commercial dairy farms. Animal 2014, 8, 1540-1546.

15. Eckard, R. J.; Grainger, C.; de Klein, C.A.M. Options for the abatement of methane and nitrous oxide from ruminant production: A review. Livest. Sci. 2010, 130, 47-56.

16. Garnsworthy, P.C.; Craigon, J.; Hernandez-Medrano, J.H.; Saunders, N. On-farm methane measurements during milking correlate with total methane production by individual dairy cows. J. Dairy Sci. 2012b, 95, 3166-3180.

17. Lassen, J.; Løvendahl, P. Heritability for enteric methane emission from Danish Holstein cows using a non-invasive FTIR method. Advances in Animal Biosciences 2013, 4, 441.

18. Pryce, J.E.; van der Werf, J.H.J.; Haile-Mariam, M.; Malcolm, B.; Goddard, M.E. Updated index weights for the Australian Profit Ranking in dairy. In Proceedings of the Association for the Advancement of Animal Breeding and Genetics. Australia, 2009.

19. Wall, E.; Simm, G.; Moran, D. Developing breeding schemes to assist mitigation of greenhouse gas emissions. Animal 2010a, 4, 366-376.

20. van de Haar, M.J.; St Pierre, N. Major advances in nutrition: relevance to the sustainability of the dairy industry. J. Dairy Sci. 2006, 89, 1280-1291.

21. Hegarty, R.S.; Goopy, J.P.; Herd, R.M.; McCorkell, B. Cattle selected for lower residual feed intake have reduced daily methane production. J. Anim. Sci. 2007, 85, 1479-1486.

22. Yan, T.; Mayne, C.S.; Gordon, F.G.; Porter, M.G.; Agnew, R.E.; Patterson, D.C.; Ferris, C.P.; Kilpatrick, D. J. Mitigation of enteric methane emissions through improving efficiency of energy utilization and productivity in lactating dairy cows. J. Dairy Sci. 2010, 93, 2630-2638.

23. Jones, H. E.; Warkup, C. C.; Williams, A.; Audsley, E. The effect of genetic improvement on emission from livestock systems. In Proceedings of the European Association of Animal Production. Lithuania, Vilnius, 2008; p.28.

24. Bell, M. J.; Wall, E.; Russell, G.; Simm, G. Effect of breeding for milk yield, diet, and management on enteric methane emissions from dairy cows. Anim. Prod. Sci. 2010, 50, 817-826.

25. Centre for Dairy Information (CDI). Available online: http://ukcows.com/thecdi/ (accessed on 25 November 2015).

26. Bell, M.J.; Eckard, R.J.; Haile-Mariam, M.; Pryce, J.E. The effect of changing cow production and fitness traits on net income and greenhouse gas emissions from Australian Dairy systems. J. Dairy Sci. 2013, 96, 7918-7931.

27. Bell, M.J.; Garnsworthy, P.C.; Stott, A.W.; Pryce, J.E. The effect of changing cow production and fitness traits on profit and greenhouse gas emissions from UK Dairy systems. .J Agric. Sci. 2015, 153, 138-151

28. Stott, A.W.; Veerkamp, R.F.; Wassell, T.R. The economics of fertility in the dairy herd. Anim. Sci. 1999, 68, 49-57.

29. Agricultural and Food Research Council (AFRC). Energy and protein requirements of ruminants. CAB International, Wallingford, Oxon, UK, 1993.

30. Wainman, F.W.; Dewy, P.J.S.; Boyne, A.W. Feedingstuffs Evaluation Unit, Third Report 1981. Rowett Research Institute, Aberdeen, UK, 1981. 
31. Wang, C.J.; Tas, B.M.; Glindemann, T.; Rave, G.; Schmidt, L.; Weißbach, F.; Susenbet A. Anim. Feed Sci. Tech. 2009, 149, 199-208

32. Redman, G. The John Nix Farm Management Pocketbook 2016. Agro Business Consultants Ltd, Melton Mowbray, UK, 2015.

33. Bell, M.; Eckard, R.; Moate, P.J.; Yan, T. Modelling the effect of diet composition on enteric methane emissions across sheep, beef cattle and dairy cows. Animals 2016, submitted.

34. Bell, M.J.; Wall, E.; Russell, G.; Roberts, D.J.; Simm, G. Risk factors for culling in Holstein-Friesian dairy cows. Vet. Record 2010, 167, 238-240.

35. de Haas, Y.; Veerkamp, R.F.; Barkema, H.W.; Gröhn, Y.T.; Schukken, Y.H.. Associations between pathogen-specific cases of clinical mastitis and somatic cell count patterns. J. Dairy Sci. 2004, 87, 95-105.

36. Kossaibati, M.A.; Esslemont, R.J. The cost of production diseases in dairy herds in England. Vet.J. 1997, 154, 41-51.

37. Pritchard, T.; Coffey, M.; Mrode, R.; Wall, E. Genetic parameters for production, health, fertility and longevity traits in dairy cows. Animal 2012, 7, 34-46.

38. Bell, M.; Wall, E.; Russell, G. Simm, G.; Stott, A. The effect of improving cow productivity, fertility, and longevity on the global warming potential of dairy systems. J. Dairy Sci. 2011, 94, 3662-3678.

39. Veerkamp, R.F.; Brotherstone, S. Genetic correlations between linear type traits, food intake, live weight and condition score in Holstein Friesian dairy cattle. Anim. Sci. 1997, 64, 385-392.

40. Banos, G.; Coffey, M.P.; Wall, E.; Brotherstone, S. Genetic relationship between first-lactation body energy and later-life udder health in dairy cattle. J. Dairy Sci. 2006, 89, 2222-2232.

41. Veerkamp, R.F.; Emmans, G.C.; Cromie, A.R.; Simm, G. Variance components for residual feed intake in dairy cows. Livest. Prod. Sci. 1995, 41, 111-120.

42. Cottle, D.J.; Conington, J. Breeding for reduced methane emissions in extensive UK sheep systems. J. Agric. Sci. 2012, 150, 570-583.

43. Price, R.; Thornton, S.; Nelson, S. The social cost of carbon and the shadow price of carbon: What they are, and how to use them in economic appraisal in the UK. Available online: https://www.gov.uk/government/ collections/carbon-valuation--2 (accessed on 25 November 2015).

44. Wall, E.; Ludemann, C.; Jones, H.; Audsley, E.; Moran, D.; Roughsedge, T.; Amer, P. The potential for reducing greenhouse gas emissions for sheep and cattle in the UK using genetic selection (FGG0808). Final report to Defra. Defra, London, UK, 2010.

45. Stott, A.W.; Coffey, M.P.; Brotherstone, S. Including lameness and mastitis in a profit index for dairy cattle. Anim. Sci. 2005, 80, 41-52.

46. Veerkamp, R.F. Selection for economic efficiency of dairy cattle using information on live weight and feed intake: A Review. J Dairy Sci. 1998, 81, 1109-1119.

47. Münger, A.; Kreuzer, M.. Absence of persistent methane emission differences in three breeds of dairy cows. Aust. J. Exp. Agr., 2008, 48:77-82.

48. Martin, C.; Morgavi, D.P.; Doreau, M. Methane mitigation in ruminants: from microbe to the farm scale. Animal, 2010, 4, 351-365.

49. Appuhamy, J.A.D.R.N; France, J.; Kebreab, E. Models for predicting enteric methane emissions from dairy cows in North America, Europe, and Australia and New Zealand. Glob. Change. Biol. 2016, doi:10.1111/ gcb.13339. 


\section{APPENDIX}

Table A. Modelled1 incidence of mastitis, lameness, uterine discharge, retained placenta, milk fever, twin birth, oestrus not observed and assisted birth for an average herd in the baseline situation and lactations 1 to 12

\begin{tabular}{|l|l|l|l|l|l|l|l|l|l|}
\hline $\begin{array}{l}\text { Age } \\
\text { group }\end{array}$ & $\begin{array}{l}\text { Clinical } \\
\text { masti- } \\
\text { tis }\end{array}$ & $\begin{array}{l}\text { Subclini- } \\
\text { cal mas- } \\
\text { titis }\end{array}$ & $\begin{array}{l}\text { Lame- } \\
\text { ness }\end{array}$ & $\begin{array}{l}\text { Uterine } \\
\text { dis- } \\
\text { charge }\end{array}$ & $\begin{array}{l}\text { Re- } \\
\text { tained } \\
\text { pla- } \\
\text { centa }\end{array}$ & $\begin{array}{l}\text { Milk } \\
\text { fever }\end{array}$ & $\begin{array}{l}\text { Twin } \\
\text { birth }\end{array}$ & $\begin{array}{l}\text { Oestrus not } \\
\text { observed }\end{array}$ & $\begin{array}{l}\text { Assisted } \\
\text { birth }\end{array}$ \\
\hline 1 & 9.8 & 3.2 & 35.8 & 18.7 & 4.5 & 0.0 & 2.2 & 41.5 & 29.5 \\
\hline 2 & 16.5 & 0.5 & 39.3 & 14.6 & 4.5 & 2.9 & 4.4 & 44.3 & 14.0 \\
\hline 3 & 20.0 & 4.9 & 42.4 & 13.8 & 5.4 & 6.8 & 6.0 & 43.6 & 8.0 \\
\hline 4 & 21.5 & 11.5 & 45.3 & 15.1 & 7.0 & 10.2 & 7.1 & 40.4 & 8.2 \\
\hline 5 & 22.1 & 17.9 & 47.8 & 17.2 & 8.6 & 12.9 & 7.7 & 35.7 & 11.3 \\
\hline 6 & 22.7 & 23.0 & 50.1 & 19.1 & 10.1 & 14.5 & 8.0 & 30.5 & 14.1 \\
\hline 7 & 24.5 & 24.7 & 52.1 & 19.5 & 10.8 & 14.8 & 8.0 & 25.9 & 13.1 \\
\hline 8 & 28.6 & 22.7 & 53.8 & 17.2 & 10.5 & 13.4 & 7.7 & 22.9 & 5.2 \\
\hline 9 & 36.0 & 16.1 & 55.2 & 11.0 & 8.6 & 10.0 & 7.2 & 22.5 & 0.0 \\
\hline 10 & 47.8 & 5.3 & 56.4 & 0.0 & 4.8 & 4.4 & 6.5 & 25.7 & 0.0 \\
\hline 11 & 47.8 & 6.1 & 57.3 & 0.0 & 0.0 & 0.0 & 5.8 & 33.6 & 0.0 \\
\hline 12 & 47.8 & 2.6 & 57.9 & 0.0 & 0.0 & 0.0 & 5.1 & 47.1 & 0.0 \\
\hline
\end{tabular}

${ }^{1}$ Values obtained from Bell et al. [34] and modelled across the 12 age groups using third order polynomials. The methodology for costs associated with an incidence of mastitis and lameness (Table B) were based on Kossaibati and Esslemont [36], except for the exclusion of costs associated with culling or extending calving intervals, which are already accounted for in the model. The costs of treatment for mastitis and lameness were revised [27], as well as the costs of discarded and reduced milk based on current modelled herd.

Table B. Costs ( $E$ unless otherwise shown) of health and fertility problems

\begin{tabular}{|c|c|c|c|c|c|c|c|c|c|c|c|c|c|c|c|c|}
\hline & \begin{tabular}{|l} 
Masti- \\
tis
\end{tabular} & & & & $\begin{array}{l}\text { Lame- } \\
\text { ness }\end{array}$ & & & $\begin{array}{l}\text { Uterine } \\
\text { dis- } \\
\text { charge }\end{array}$ & \begin{tabular}{|l|} 
Re- \\
tained \\
pla- \\
centa
\end{tabular} & \begin{tabular}{|l|} 
Milk \\
fever
\end{tabular} & & & $\begin{array}{l}\text { Twin } \\
\text { birth }\end{array}$ & $\begin{array}{l}\text { Oestrus } \\
\text { not ob- } \\
\text { served }\end{array}$ & \begin{tabular}{|l|} 
As- \\
sisted \\
birth \\
\end{tabular} & \\
\hline & Clinical & & & \begin{tabular}{|l}
$\begin{array}{l}\text { Sub- } \\
\text { clini- } \\
\text { cal }\end{array}$ \\
\end{tabular} & Clinical & & & & & & & & & & & \\
\hline & Severe & Mild & Fatal & & Digital & \begin{tabular}{|l|} 
Inter- \\
digital
\end{tabular} & \begin{tabular}{|l|l|}
$\begin{array}{l}\text { Sole } \\
\text { ulcer }\end{array}$ \\
\end{tabular} & & & Severe & Mild & Fatal & & & Farm & Vet \\
\hline \begin{tabular}{|l} 
Prevalence $^{1}$ \\
\end{tabular} & 0.15 & 0.84 & 0.01 & & 0.47 & 0.22 & 0.31 & & & 0.05 & 0.87 & 0.08 & & & 0.82 & 0.18 \\
\hline Treatment $^{a}$ & 40.00 & 5.58 & 40.00 & & 12.90 & 11.28 & 12.01 & 10.81 & 6.25 & 8.00 & 5.00 & 18.00 & & 5.30 & & \\
\hline Vet visit ${ }^{\mathrm{t} 2}$ & 62.50 & & 62.50 & & 18.75 & 15.00 & 25.00 & & & 37.5 & & 66.25 & & 6.25 & & 75.00 \\
\hline Herdsman's time ${ }^{\mathrm{c}^{2}}$ & 5.00 & 2.50 & & & 30.00 & 10.00 & 50.00 & & & 10.00 & 10.00 & 10.00 & 10.00 & & 10.00 & \\
\hline Discarded milk ${ }^{\mathrm{d} 2}$ & 59.89 & 46.58 & & & 46.58 & 33.27 & 39.93 & & & & & & & & & \\
\hline \begin{tabular}{|l} 
Reduced yield \\
\end{tabular} & 94.76 & 52.73 & & 52.73 & 80.24 & 45.85 & 126.09 & 71.07 & 91.7 & 119.21 & 48.14 & & -57.31 & & & \\
\hline Per case & 262.15 & 107.39 & 102.50 & 52.73 & 188.47 & 115.40 & 253.03 & 81.88 & 97.95 & 174.71 & 63.14 & 94.25 & -47.31 & 11.55 & 10.00 & 75.00 \\
\hline $\begin{array}{l}\text { Per repeat case } \\
(a+b+c+d)\end{array}$ & 167.39 & 54.66 & & & 108.23 & 69.55 & 126.94 & 10.81 & & & & & & 11.55 & & \\
\hline Total per cow ${ }^{3}$ & 329.11 & 129.26 & 102.50 & 52.73 & 231.76 & 143.22 & 303.80 & 86.20 & 97.95 & 174.71 & 63.14 & 94.25 & -47.31 & 16.17 & 10.00 & 75.00 \\
\hline \begin{tabular}{|l|}
$\begin{array}{l}\text { Cost per incidence } \\
\text { based on prevalence }\end{array}$ \\
\end{tabular} & 158.97 & & & 52.73 & 234.62 & & & 86.20 & 97.95 & 71.21 & & & -47.31 & \begin{tabular}{|l|}
16.17 \\
\end{tabular} & \begin{tabular}{|l|}
21.70 \\
\end{tabular} & \\
\hline $\begin{array}{l}\begin{array}{l}\text { Discarded milk per } \\
\text { case (litres) }\end{array} \\
\end{array}$ & 336.98 & 262.10 & & & 262.10 & 187.21 & 224.66 & & & & & & & & & \\
\hline $\begin{array}{l}\text { Discarded milk per } \\
\text { incidence (litres) }\end{array}$ & 270.71 & & & & 234.02 & & & & & & & & & & & \\
\hline
\end{tabular}


${ }^{1}$ Prevalence of cases reported by Kossaibati and Esslemont [36] were used for lameness and milk fever, whereas the prevalence of mild and severe clinical mastitis was changed to represent current levels [27].

${ }^{2}$ Veterinarian's time at $£ 75$ per hour; Labour at $£ 10$ per hour; Milk discarded for 9 and 7 days for a severe and mild clinical case of mastitis and 7, 5 and 6 days for a digital, interdigital and sole ulcer clinical case of lameness respectively; Milk reduced by 4.1 and 2.3\% for a severe and mild clinical case of mastitis, $3.5,2$ and 5.5\% for a digital, interdigital and sole ulcer clinical case of lameness, 3.1\% for uterine discharge, $4 \%$ for retained placenta, 5.2 and $2.1 \%$ for severe and mild milk fever and increased by $2.5 \%$ for a twin birth respectively.

${ }^{3}$ Assuming cows average 1.4 cases per incidence of severe and mild mastitis and clinical lameness [37], uterine discharge and oestrus not observed.

Table C. Input and output costs calculated for the baseline steady state herd per cow

\begin{tabular}{|l|l|}
\hline Output & Per $\operatorname{Cow}(\boldsymbol{E})$ \\
\hline Milk Sales & $£ 2,106.20$ \\
\hline Calves & $£ 74.37$ \\
\hline Culls & $£ 129.67$ \\
\hline Less & \\
\hline Replacements & $-£ 387.30$ \\
\hline Total Output & $£ 1,922.93$ \\
\hline Variable costs & \\
\hline Feed & $£ 1,017.74$ \\
\hline Artificial insemination & $£ 82.68$ \\
\hline Health & $£ 155.09$ \\
\hline Enterprise costs & $£ 141.76$ \\
\hline Total variable costs & $£ 1,397.27$ \\
\hline Gross Margin & $£ 525.66$ \\
\hline
\end{tabular}

Citation: Matt Bell, Jennie Pryce, Paul Wilson, "A Comparison of the Economic Value for Enteric Methane Emissions with other Biological Traits Associated With Dairy Cows". ARJA Volume 2; pp:1-17

Copyright (c) 2016 Matt Bell, Jennie Pryce, Paul Wilson, This is an open access article distributed under the Creative Commons Attribution License, which permits unrestricted use, distribution, and reproduction in any medium, provided the original work is properly cited. 